DOI: $10.38035 /$ DIJEMSS

Received: $21^{\text {th }}$ August 2020, Revised: $25^{\text {th }}$ September 2020, Publish: $18^{\text {st }}$ November 2020

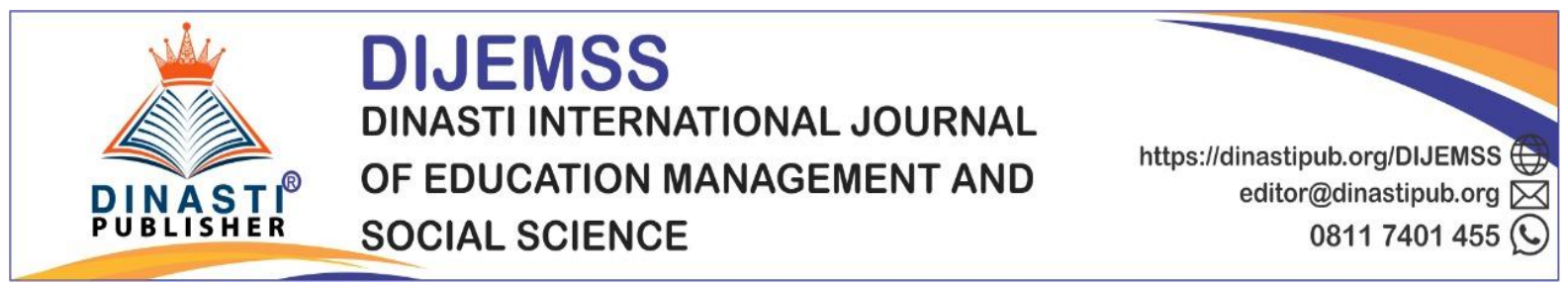

\title{
THE INFLUENCE OF CAREER DEVELOPMENT AND COMPENSATION ON WORK SATISFACTION AND ITS IMPLICATIONS AGAINST TURNOVER INTENTION AT AJB BUMIPUTERA 1912'S HEAD OFFICE
}

\author{
Didik Sulistiyono', Muhammad Havidz Aima ${ }^{2}$ \\ ${ }^{1)}$ Mercu Buana University, Jakarta, Indonesia, didikt22@ gmail.com \\ ${ }^{2)}$ Mercu Buana University, Jakarta, Indonesia, havidz.aima@yahoo.com
}

\section{Corresponding Author: Didik Sulistiyono}

\begin{abstract}
This research aims to discovered those influence of career development and compensation towards turnover intention that mediated through work satisfaction. The research object were the employees of AJB Bumiputera 1912's head office. As many as 177 respondents filled these questionnaire, and sample was taken by Slovin formula from total population of 317 employees. This research was conducted in October 2019 until April 2020 at AJB Bumiputera 1912's head office. The sampling technique used proportional stratified random sampling while data were analyzed by SmartPLS (Partial Least Square)of path analysis application. The results from this research were indicated that career development had no significant influence on Turnover Intention and compensation had positive and significant impact towards turnover intention. Meanwhile, work satisfaction became a mediate factor between career development and compensation to turnover intention. Work satisfaction could mediated career development perfectly. And work satisfaction only had partial impact towards compensation.
\end{abstract}

Keywords: Career Development, Compensation, Work Satisfaction, Turnover Intention.

\section{INTRODUCTION}

\section{Background of Problem}

Human resources are very important factor in which carrying out those activities from a company. To obtained good human resources, it should be managed in professional and directed manner, starting from recruiting, interviewing, selecting, training, developing, providing remuneration to employee maintenance.

An increase in turnover is one problem that should be considered because it could affect the condition of company. If the desire to move within a company is high, it will cause several negative influence in form of instability which could ultimately harm the company and its employees.

AJB Bumiputera 1912 is the only insurance company in form of mutual insurance that means it is a joint venture and Policyholder himself is the owner of company. Many policyholders do not know that they were the owner of the company, management related to 
business processes and evaluation of company performance including how the recruitment process, career development, compensation in the company which cannot be carried out professionally.

As the oldest insurance company in Indonesia, which has been around for 107 years. In the last ten years, AJB Bumiputera 1912 was experience decreased in assets compared to its liabilities, coupled with the large number of foreign insurers that continued to expanded the insurance market owned, this situation was exacerbated by the failure of restructuring carried out by the Financial Services Authority (OJK) which in collaboration between AJB Bumiputera 1912 and PT Evergreen Invesco Tbk which had impacted to subsidiary of PT. Bumiputera Life turned into PT.Bhinneka Life that which separated from AJB Bumiputera 1912. This failure made by many potential employees to move to PT. Bhinneka Life with total of 200 employees from AJB Bumiputera 1912's head office which finally moved to PT. Bhinneka Life during these restructuring period in 2017 by layoff status.

This situation left many problems which caused AJB Bumiputera 1912 more unstable. This transfer creates vacancies in various important positions, because the existing management did a lot of policies, the promotion process, without going through a clear mechanism, in addition to reduced incentives and bonuses received, this could impact employee dissatisfaction and increase the desire of employees to move.

AJB Bumiputera 1912 has currently experiencing a high turnover. This could be seen based on data from last 6 years from 2014 to 2019 in these table below:

Table 1. Employee Turnover of AJB Bumiputera 1912's Head Office

\begin{tabular}{cccc}
\hline Year & Total Employee (Person) & Resign (Person) & Percentage \\
\hline 2014 & 562 & 11 & $1,95 \%$ \\
2015 & 551 & 14 & $2,54 \%$ \\
2016 & 540 & 8 & $1,48 \%$ \\
2017 & 323 & 13 & $4,02 \%$ \\
2018 & 334 & 18 & $5,38 \%$ \\
2019 (until Oct) & 317 & 6 & $1,89 \%$ \\
\hline
\end{tabular}

Source: Data based on Human Resources Dept from Head Office

Based on Table 1 above, it could be said that the number of turnover in AJB Bumiputera 1912 over the last six years has been fluctuated where the percentage of turnover increased in 2018 was quite high of $5.38 \%$.

\section{LITERATURE REVIEW}

\section{Career Development}

According to Kasmir, (2016:161) Career is a position and level that a person earned at work. In other words, career is the way of life from employee during his/her working life. According to Dessler (2013:253) career development is a lifelong series of activities that contribute to someone's career exploration, establishment, success and satisfaction.

According to Sunyoto (2012:166) dimensions and indicators from career development consist of: 
1) Career planning

Career planning is the process through individual employees identify and take steps to achieve their career goals. Career planning process consists of: a) Match between interests and skills at work; b) Career development opportunities within the company; and c) Clarity of long-term and short-term career plans.

2) Career management

Career management is a continuous process by preparing, implementing and monitoring career plans which carried out by individuals themselves or due to organization's career system. Career management consists of: a) Integrate with human resource planning; b) Spread career information about job vacancies Education and training publicly.

\section{Compensation}

Kadarisman (2012: 49) in Ganjar and Havidz (2018) states that compensation is an award that given to employees fairly and properly through work performance and services that have been issued towards organization goals in order to achieve its goals.

According to Kasmir (2016:240) compensation was divided into two types, which is:

1) Financial compensation

Compensation given in form of money. This type of compensation was consisted of payments, wages, bonuses, commissions, and incentives.

2) Non-financial compensation.

Compensation given in form of allowances to improve employee welfare, both physically and mentally. In general, it consists of health allowances, child / wife allowances, housing allowances, vehicle allowances, etc.

\section{Work Satisfaction}

According to Robbins and Judge (2013:108) work satisfaction is a picture of a someone's positive feelings regards their work, employees who were satisfied with their work, would tend to have high positive feelings to work they do. rather, these employees who were not satisfied with the work they did have high negative feelings about their work.

The dimensions of work satisfaction according to Mathis and Jackson (2013:158) are:

1) The work itself (aspects of duties and work), consists of: a) Work who has fun/or work to be proud off; b) Facilities \& technology that support work; and c) Workplace comfort.

2) Salary aspect, consisting of: a) The relevance of salary at work; and b) Rewards and its incentives should be based on work performance.

3) Recognition (aspects of relationships with coworkers), which consist of: a) Cooperative coworkers; and b) Social needs to interact with colleagues.

4) Relations between supervisors and employees (aspects of superior relations), that consisted of: a) Duties from superiors; b) Decision-making; and c) Superior's response.

5) Promotion (opportunity to advance), consist of: a) Mutation opportunity; and b) Promotion opportunity.

\section{Turnover Intention}

Turnover is a form of employee withdrawal to separate themselves from the company. Mathis and Jackson (2011:159) stated that turnover is a process when an employee leaves an 
organization and leaves job position and where that position should be replaced by someone else.

According to Mobley (2011:150) there are three indicators that used to measure turnover intention, such as:

1) Thoughts of quitting

In Beginning with job dissatisfaction which felt by employee, then employee begin to think about leaving their current place of work and resulting in high and low intensity for not coming to their place of work (absenteeism)

2) Desire to leave

If the employee has started to often think about leaving their current job, the employee will try to find a new job outside the company where he works which they feels better.

3) The desire to find another job

An employee intend to leave when they have a better job, sooner or later will result to employee's decision to stay or leave their job.

\section{RESEARH METHODS}

\section{Population}

These research population were all employees from AJB Bumiputera 1912 Head Office, which amounted to 177 people. There had no sampling for data collection also these research was conducted by census system.

\section{Data Collection Techniques and Variable Measurement}

In this research, the data source used primary data, which is the source of research data obtained directly from the respondents' information thats extracted by direct observation on the field through questionnaire according to variables requested from the research location.

\section{Research Instrument Test}

1) Validity test

These validity test is a tool used to measure whether a questionnaire is valid or not. to examined these validity of reflexive indicators needs to carried out in two stages. First stage is convergent validity test, namely Determine the validity based on loading factor value of each construct, and the next stage is examined discriminant validity, such as test these validity based on comparisons. (Ghozali and Latan, 2015).

2) Reliability Test

Reliability test is a test tool to measure the construct reliability from latent variables as measured by two kinds of measures, which is composite by reliability and Cronbach alpha from indicator block to measuring the construct.

\section{Quantitative Analysis Data Techniques}

This research used analysis method by Structural Equation Modeling (SEM) with instrument test used Partial Least Square (PLS) method. Partial Least Squares (PLS) analysis is a multivariate statistical technique that performs comparisons between multiple dependent variables and multiple independent variables (Jogiyanto, 2011:55). 


\section{Analysis of Determination Coefficient of $\left(\mathbf{R}^{\mathbf{2}}\right)$}

These determination coefficient $\left(\mathrm{R}^{2}\right)$ in essence measures how far these ability to explain the variation in this dependent variable.

\section{Predictive Relevance $\mathbf{Q}^{2}$ value}

This evaluation from PLS model was also carried out by $\mathrm{Q}^{2}$ predictive relevance or often called predictive sample reuse. If these value of $\mathrm{Q}^{2}>0$ it was indicated that the model had predictive relevance, while these value of $\mathrm{Q}^{2}<0$ was indicated that the model has less predictive relevance.

\section{Goodness of Fit Index (GoF) Value}

The Goodness of Fit (Gof) index was developed to evaluate these Measurement model and structural model and besides providing a simple measurement model for overall model prediction. For this reason, the $\mathrm{GoF}$ index was calculated $\mathrm{GoF}=\sqrt{A V E \times R^{2}}$ from the square root of average comunality index and average $\mathrm{R}$-squares values as its follows:

Regarding the criteria for determining whether the model is fit or not, in Ghozali and Latan (2015:83) the value of small $\mathrm{GoF}=0.10$, medium $\mathrm{GoF}=0.25$, and large $\mathrm{GoF}=0.36$.

\section{Hypothesis Test}

Furthermore, evaluation through model was carried out by significance value to determine these influence between variables through bootstrapping procedure. The structural model test could be done by paying attention to output path coefficient value . To determine whether there has an influence of exogenous variables on endogenous variables, it could find out based on the P-value. This to determine the level of significance determined based on tstatistics. The influence from lots of magnitude from exogenous variables on endogenous variables that could be seen from y value in original sample.

\section{RESULT AND DISCUSSION \\ Respondent Profile}

Data which gathered from questionnaires that distributed to respondents to employee from AJB Bumiputera1912's Head office which total of 177 people. From 177 questionnaires distributed, 177 complete and eligible data were obtained for verification, profiles including age, gender, education level and years of service at the company.

\section{Evaluation of Measurement Model (Outer Model) Validity Test}

\section{1) Convergent Validity}

According to Ghozali, indicator was considers to have higher level of validity which having a loading factor value greater than 0.70 . These calculating result had loading factor of each variable indicator were as follows:

\section{Career Development (X1)}


It could be seen that indicators from career development each had loading factor value of $>0.70$. This shows that these six indicators from career development variables were valid.

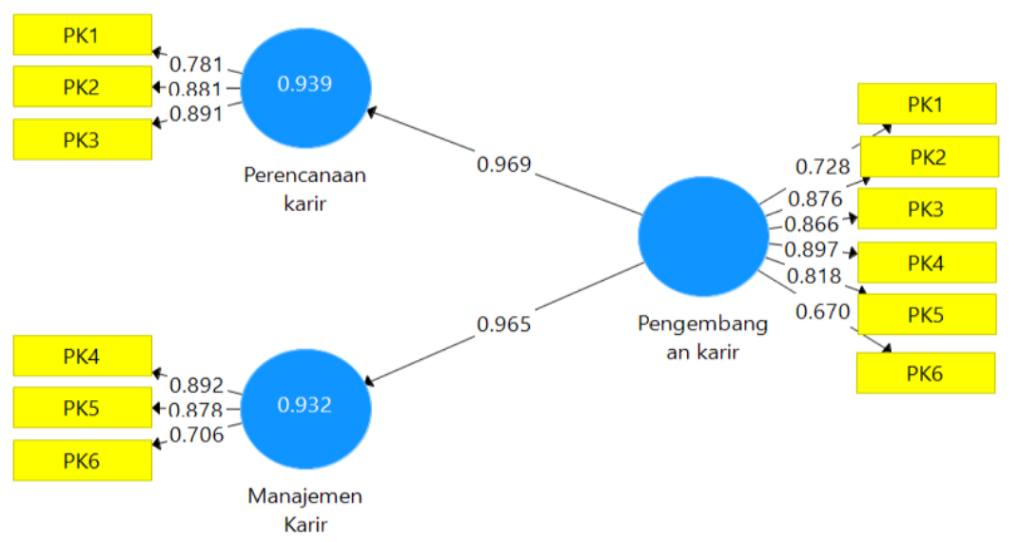

Figure 1. Outer Model of Career Development

\section{Compensation (X2)}

It could be seen that indicators from compensation variable each had loading factor value $>0.70$. This shows that six indicators from compensation variable were valid

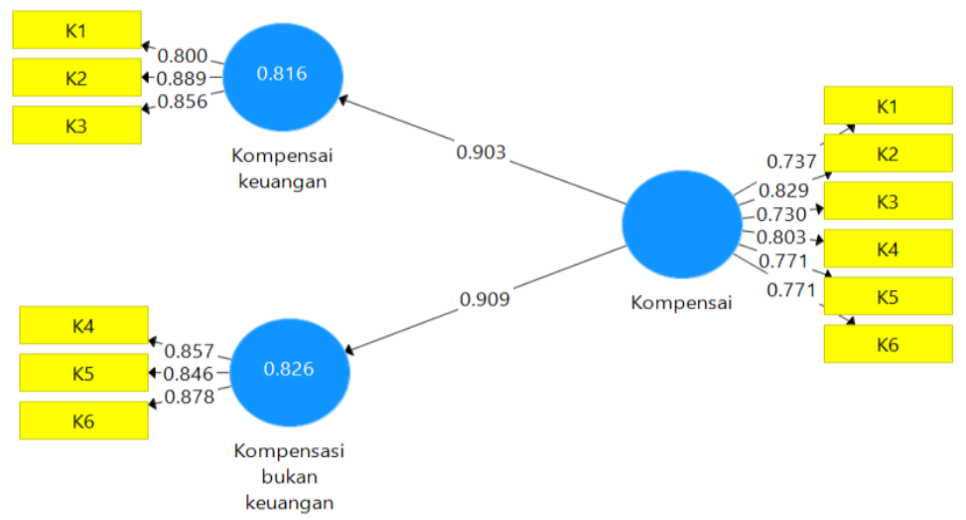

Figure 2. Outer Model of Compensation

\section{Work Satisfaction (Y1)}

It could be seen that these indicators from each work satisfaction variables had loading factor value of $>0.70$. This shows that eleven out of twelve indicators of work satisfaction variables were declared valid and still used in these model or not removed from the model.

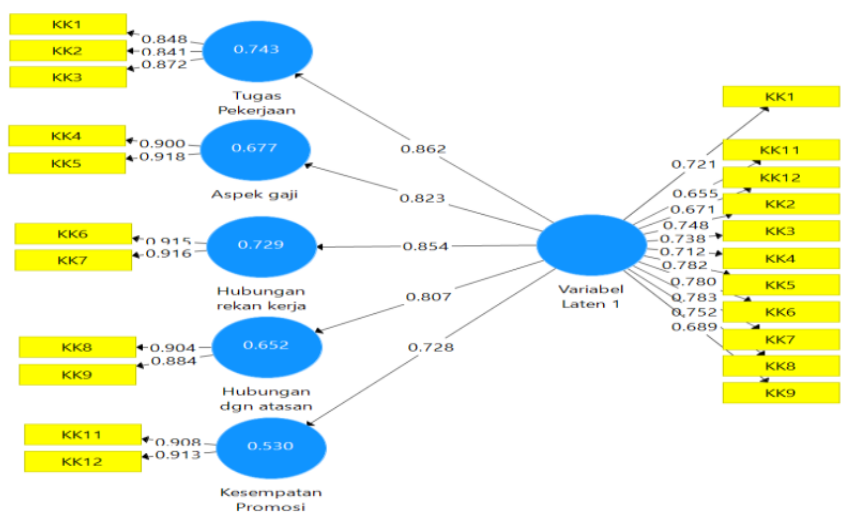




\section{Figure 3. Outer Model of Work Satisfaction}

\section{Turnover Intention variable (Y2)}

It could be seen that indicators of turnover intention variable each had loading factor value of $>0.70$. This shows that four out of five variable indicators were valid and still used as model or were excluded from model.

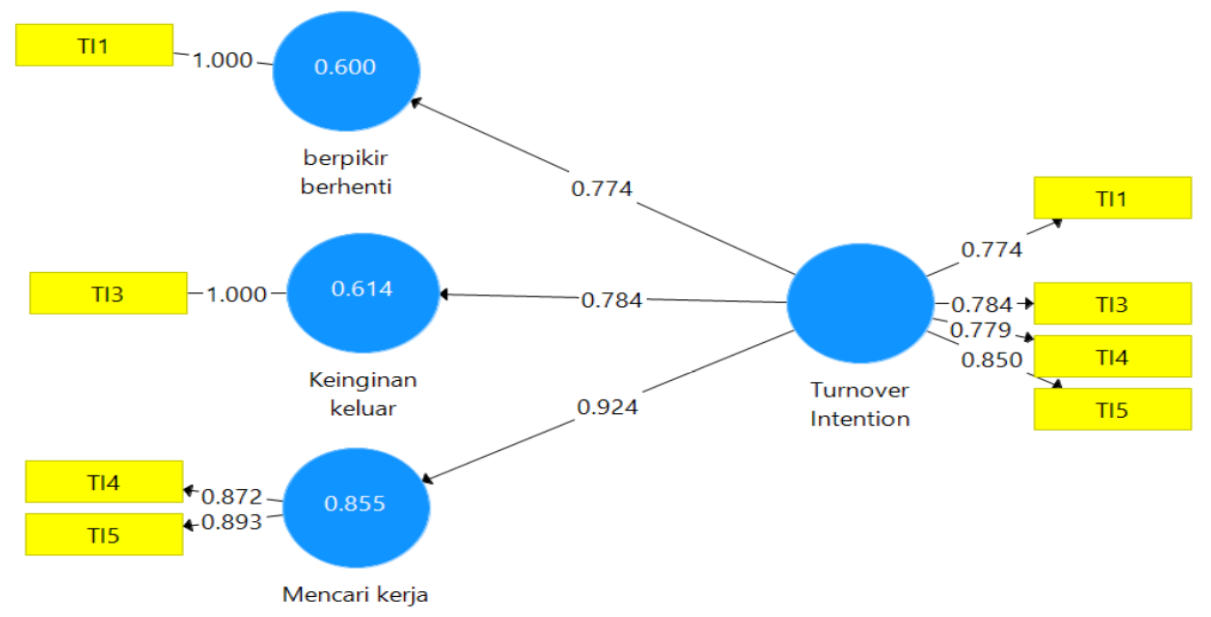

Figure 4. Outer Model of Turnover Intention

From Figures 1, 2, 3 and 4, it could be seen from table above that loading factor of each indicator had $>0.7$. This proven that all indicators used in this research were valid or met the convergent validity.

\section{2) Discriminant Validity}

If the value from construct value with measurement item was greater than correlation value by other constructs, then this shows that latent construct predicts the size of their block better than others, and its said that the construct has high Discriminant Validity (Ghozali, 2015). Following these results from Discriminant Validity from cross loading value between these indicators and their respective constructs:

Table 2. Cross Loading Values of Variables and Research Model Constructs 


\begin{tabular}{|l|c|c|c|c|}
\hline Indicator & Career Development & Compen sation & Work Satisfaction & Turnover Intention \\
\hline PK1 & $\mathbf{0 , 7 3 5}$ & 0,498 & 0,663 & $-0,28$ \\
\hline PK2 & $\mathbf{0 , 8 7 5}$ & 0,666 & 0,726 & $-0,424$ \\
\hline PK3 & $\mathbf{0 , 8 6 5}$ & 0,619 & 0,726 & $-0,336$ \\
\hline PK4 & $\mathbf{0 , 8 9 9}$ & 0,555 & 0,696 & $-0,409$ \\
\hline PK5 & $\mathbf{0 , 8 1 9}$ & 0,596 & 0,671 & $-0,368$ \\
\hline PK6 & $\mathbf{0 , 6 5 8}$ & 0,588 & 0,489 & $-0,24$ \\
\hline K1 & 0,48 & $\mathbf{0 , 7 3 2}$ & 0,5 & $-0,326$ \\
\hline K2 & 0,647 & $\mathbf{0 , 8 3 3}$ & 0,616 & $-0,432$ \\
\hline K3 & 0,499 & $\mathbf{0 , 7 2 3}$ & 0,469 & $-0,298$ \\
\hline K4 & 0,612 & $\mathbf{0 , 8 1}$ & 0,614 & $-0,346$ \\
\hline K5 & 0,498 & $\mathbf{0 , 7 6 5}$ & 0,483 & $-0,339$ \\
\hline K6 & 0,576 & $\mathbf{0 , 7 7 5}$ & 0,544 & $-0,388$ \\
\hline KK1 & 0,643 & 0,41 & $\mathbf{0 , 7 1 9}$ & $-0,242$ \\
\hline KK2 & 0,696 & 0,496 & $\mathbf{0 , 7 6 1}$ & $-0,4$ \\
\hline KK3 & 0,676 & 0,448 & $\mathbf{0 , 7 4 2}$ & $-0,3$ \\
\hline KK4 & 0,618 & 0,603 & $\mathbf{0 , 7 2 8}$ & $-0,435$ \\
\hline KK5 & 0,728 & 0,694 & $\mathbf{0 , 7 9 6}$ & $-0,483$ \\
\hline KK6 & 0,563 & 0,486 & $\mathbf{0 , 7 7}$ & $-0,406$ \\
\hline KK7 & 0,585 & 0,525 & $\mathbf{0 , 7 8 1}$ & $-0,386$ \\
\hline KK8 & 0,586 & 0,505 & $\mathbf{0 , 7 4 4}$ & $-0,349$ \\
\hline KK9 & 0,474 & 0,526 & $\mathbf{0 , 6 7 6}$ & $-0,372$ \\
\hline KK11 & 0,5 & 0,432 & $\mathbf{0 , 6 4 9}$ & $-0,313$ \\
\hline KK12 & 0,453 & 0,442 & $\mathbf{0 , 6 5 8}$ & $-0,293$ \\
\hline TI1 & $-0,403$ & $-0,374$ & $-0,448$ & $\mathbf{0 , 7 8 4}$ \\
\hline TI3 & $-0,366$ & $-0,395$ & $-0,439$ & $\mathbf{0 , 7 9 7}$ \\
\hline TI4 & $-0,244$ & $-0,338$ & $-0,306$ & $\mathbf{0 , 7 6 2}$ \\
\hline TI5 & $-0,326$ & $-0,357$ & $-0,382$ & $\mathbf{0 , 8 4 2}$ \\
\hline
\end{tabular}

From these Table 2 it could be seen that the construct correlation value with the indicator who has greater value than correlation value from other constructs. So it could be said that all latent constructs shows good Discriminant Validity because they could tells those indicators in their block better than any indicators in other blocks.

Furthermore, to examined this Discriminant Validity, it could be done by looking at AVE value. AVE value is good if it has value greater than 0.50 . These following are the values from AVE table:

Table 3. AVE Research Model

\begin{tabular}{|c|c|}
\hline Variable & AVE Value \\
\hline Career Development & 0,661 \\
\hline Compensation & 0,599 \\
\hline Work Satisfaction & 0,534 \\
\hline Turnover Intention & 0,635 \\
\hline
\end{tabular}

Table 3 above shows from AVE value from research model. it can be said that all research variables has been above 0.5 so AVE value for discriminant validity test met its further test. 


\section{Reliability Test}

Reliability test is a reliability test that intended to find out how reliable or trustworthy these measuring instrument is. The rule of thumb for alpha value or composite reliability should be greater than 0.7 , although a value of 0.6 still acceptable.

1) Composit Reliability

The first stage, these construct was declared reliable if it has a Composite Reliability value above 0.7. These following is the output from outer model of Composite Reliability.

Table 4. The Value of Composite Reliability from Research Model

\begin{tabular}{|c|c|c|c|}
\hline Variable & Composite reliability & Term & Information \\
\hline Career Development & 0,921 & $>0,7$ & Reliable \\
\hline Compensation & 0,899 & $>0,7$ & Reliable \\
\hline Work Satisfaction & 0,926 & $>0,7$ & Reliable \\
\hline Turnover Intention & 0,874 & $>0,7$ & Reliable \\
\hline
\end{tabular}

Table 4 above is a table from composite reliabilty values from the research model. These table shows that each variable had composite reliability value above 0.7 with the lowest value of 0.874 for Turnover Intention (Y2) variable and the highest value of 0.926 for work Satisfaction variable (Y1). From these results it could be said that the research model was obtained from the value of composite reliability.

\section{Cronbach's Alpha}

The next stage of reliability test was examined Cronbach alpha value. A construct was declared reliable if it has Cronbach alpha value above 0.60.

Table 5. Cronbach's Alpha Value from these Research Model

\begin{tabular}{|c|c|c|c|}
\hline Variable & $\begin{array}{c}\text { Cronbach } \\
\text { alpha }\end{array}$ & Term & Information \\
\hline Career Development & 0,895 & $>0,6$ & Reliable \\
\hline Compensation & 0,866 & $>0,6$ & Reliable \\
\hline Work Satisfaction & 0,912 & $>0,6$ & Reliable \\
\hline Turnover Intention & 0,809 & $>0,6$ & Reliable \\
\hline
\end{tabular}

Table 5. above is a table of Cronbach alpha values from these research model. That shows that each variable has a Cronbach alpha value above 0.6 with lowest value of 0.809 from the Turnover Intention (Y2) variable and the highest value of 0.912 from the work Satisfaction variable (Y1). Based on these results it can be concluded that research model met the value of cronbach's alpha.

\section{Evaluation of Structural Model (Inner Model)}

\section{Evaluating these Path Coefficient Value}

To evaluate these path coefficient value, based on these calculations results from SmartPLS version 3.0 bootstrapping, the path coefficient results were obtained which describes that the strength of relationship between constructs / variables as its shown in Table 6 and Figure 5. 
Table 6. Path Coefficient Testing Results

\begin{tabular}{|l|r|r|r|}
\hline \multicolumn{1}{|c|}{ Relation Between Construct } & \multicolumn{1}{c|}{$\begin{array}{c}\text { Original } \\
\text { Sample (O) }\end{array}$} & $\begin{array}{c}\text { T Statistic } \\
(\mid \mathbf{O} / \text { STDEV }]\end{array}$ & P Values \\
\hline $\begin{array}{l}\text { Career Development -> Work } \\
\text { Satisfaction }\end{array}$ & 0,6566 & 10,0116 & 0,0000 \\
\hline $\begin{array}{l}\text { Compensation - > Work } \\
\text { Satisfaction }\end{array}$ & 0,2281 & 3,3756 & 0,0008 \\
\hline $\begin{array}{l}\text { Work Satisfaction -> Turnover } \\
\text { Intention }\end{array}$ & $-0,3842$ & 3,3003 & 0,0010 \\
\hline $\begin{array}{l}\text { Career Development >> } \\
\text { Turnover Intention }\end{array}$ & $\mathbf{0 , 0 5 2 6}$ & $\mathbf{0 , 4 1 6 0}$ & $\mathbf{0 , 6 7 7 6}$ \\
\hline $\begin{array}{l}\text { Compensation - > Turnover } \\
\text { Intention }\end{array}$ & $-0,2305$ & 2,2885 & 0,0225 \\
\hline
\end{tabular}

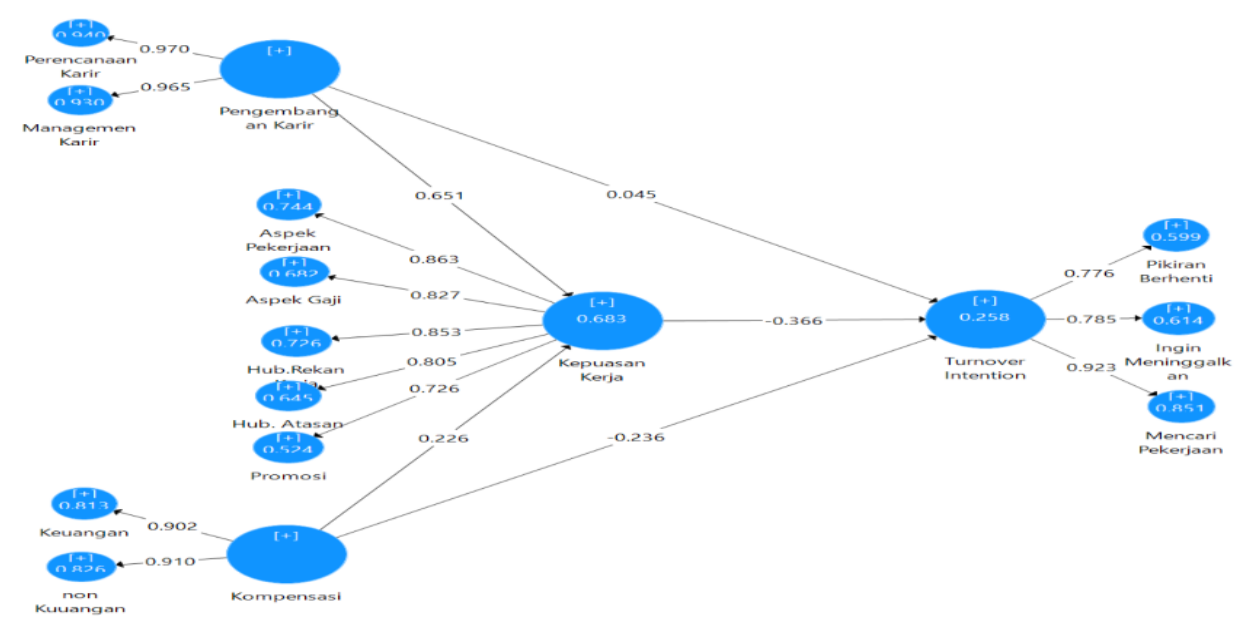

Figure 5.The Bootstrapping Inner Model Calculation Results

According to Figure 5. The structural equation from this research could be formulated as its follows:

Work Satisfaction $(\mathrm{Y} 1)=0.657 \gamma 1+0.228 \gamma 2$

Turnover Intention $(Y 2)=0.053 \gamma 3+-0,230 \gamma 4+-0,384 \beta$

Based on table 5 it could be concluded that:

1) Career development had significant influence of 0.657 towards work satisfaction with $\mathrm{T}$ Statistic value of 10.012 and P-value of 0.000 .

2) Career development had none significant impact around 0.053 towards turnover intention with T-Statistic value was 0.417 and P-Values was 0.677.

3) Compensation had significant impact on work satisfaction around of 0.228 with T-Statistic value was 3.375 and P-Values was 0.0008 .

4) Compensation had significant impact over $-0,230$ to turnover intention with T-Statistic value was 2,289 and P-Values was 0.022 .

5) Work satisfaction had significant affect around $-0,384$ to Turnover Intention with T-Statistic value was 3,300 and P-Values was 0.001 . 


\section{R-Square Value}

Inner model evaluation has done by looking at coefficient of determination. The coefficient of determination aims to measure those extent to which model was able to explain the variance of dependent variable. The coefficient of determination is between 0 and 1 . The coefficient of determination (R2) was close to the value of 1, which explained that the size of independent variable hypothesized in equation and capable to explain those dependent variable. Chin (1998) (in Ghozali and Latan, 2015, 78) describes the criteria for limiting the value of $\mathrm{R}^{2}$ in this three classifications, namely the values of $\mathrm{R}^{2}=0.67,0.33$ and 0.19 as substantial, moderate, and weak.

Table 7. Value of $\mathbf{R}$ Square $\left(\mathbf{R}^{2}\right)$ from the Research Model

\begin{tabular}{l|c|c|}
\hline \multicolumn{1}{c|}{ Construct } & R Square & Adjusted R Square \\
\hline Work Satisfaction & 0,698 & 0,695 \\
\hline Turnover Intention & 0,277 & 0,264 \\
\hline
\end{tabular}

Seen fromTable 7above, the relationship between constructs based on R-square value could be explained as follows:

1) R-square value from work Satisfaction variable (Y1) was 0.698. This shows that $69.80 \%$ of work Satisfaction variable (Y1) could be influenced by Career Development variable (X1) and Compensation variable (X2) while the remaining $30.20 \%$ was influenced by other variables outside the research

2) R-square value on turnover Intention (Y2) variable was 0.277 , this indicates that $27.70 \%$ from Turnover Intention (Y2) variable could be influenced by Career Development (X1), Compensation (X2) and work Satisfaction (Y1) variables. while the remaining $72.30 \%$ was influenced by other variables outside these research.

\section{$Q^{2}$ Predictive Relevance}

The value of $\mathrm{Q}^{2}$ could be calculated by these following formula:

$\mathrm{Q}^{2}=1-\left(\left(1-\mathrm{R} 1^{2}\right)\left(1-\mathrm{R} 2^{2}\right) \ldots\left(1-\mathrm{Rx}^{2}\right)\right)=1-\left(\left(1-0.698^{2}\right)\left(1-0.277^{2}\right)\right)=0.527$

From these calculation results above, it could be estimated that value of $\mathrm{Q}^{2}$ was greater than 0 (zero), so these model had predictive relevance value, therefore the observation value which generated by the model and parameter estimation was good / relevant.

\section{Goodness of Fit Index (GoF) Value}

The Goodness of Fit Index (Gof) was calculated manually from the square root of the mean communality index values and the average $\mathrm{R}$-squares as follows

GoF Index $=\sqrt{A V E \times R^{2}}=0.713$

Then GoF Index value was considered as large because the value is more than 0.36 . This indicates that the model as a whole was suitable.

\section{Hypothesis Testing}

Hypothesis test between constructs was carried out by bootstrap resampling method. Estimation from this hypothesis by SmartPls 3.2.7 could be seen from the Path Coefficient 
value. To discover whether there has an influence between exogenous variables on endogenous variables, it can be seen based on these P-Value. To determine the level of significance obtained based on $\mathrm{T}$ statistic. Meanwhile, to find out the strength of influence of exogenous variables on endogenous variables, it can be seen based on original sample value

The $t$ test statistic using formula or by SmartPLS 3.2.7 like could be seen from the comparison between $\mathrm{t}$ test value and $\mathrm{t}$ table value like obtained from these formula:

$\mathrm{DF}=\mathrm{nk}-1=177-3=174$

In this statistical table, $t$ table value with a value of 174 was 1.97 with a significance level $(\alpha)$ of 0.05 . The way to make a decision was:

- If P-Values $>0.05$ or $\mathrm{t}$ count $<\mathrm{t}$ table, Ho was accepted

- If P-Values $<0.05$ or $\mathrm{t}$ count $>\mathrm{t}$ table, Ho was rejected

The results from statistical calculations with Smart PLS version 3.0 program were presented in Table 8 and Table 9 below.

Table 8. Hypothesis Test for Direct Effects

\begin{tabular}{|l|r|r|r|c|}
\hline \multicolumn{1}{|c|}{ Relation Between Construct } & $\begin{array}{c}\text { Original } \\
\text { Sample (O) }\end{array}$ & $\begin{array}{c}\text { T Statistic } \\
(\mid \mathrm{O} / \text { STDEV })\end{array}$ & T Table & $\begin{array}{c}\text { P } \\
\text { Values }\end{array}$ \\
\hline $\begin{array}{l}\text { Career Development -> Work } \\
\text { Satisfaction }\end{array}$ & 0,6566 & 10,0116 & 1,97 & 0,0000 \\
\hline $\begin{array}{l}\text { Compensation -> Work } \\
\text { Satisfaction }\end{array}$ & 0,2281 & 3,3756 & 1,97 & 0,0008 \\
\hline $\begin{array}{l}\text { Work Satisfaction -> Turnover } \\
\text { Intention }\end{array}$ & $-0,3842$ & 3,3003 & 1,97 & 0,0010 \\
\hline $\begin{array}{l}\text { Career Development > } \\
\text { Turnover Intention }\end{array}$ & $\mathbf{0 , 0 5 2 6}$ & $\mathbf{0 , 4 1 6 0}$ & $\mathbf{1 , 9 7}$ & $\mathbf{0 , 6 7 7 6}$ \\
\hline $\begin{array}{l}\text { Compensation -> Turnover } \\
\text { Intention }\end{array}$ & $-0,2305$ & 2,2885 & 1.97 & 0,0225 \\
\hline
\end{tabular}

Table 9. Hypothesis Test for Indirect Effects

\begin{tabular}{|l|c|c|c|c|}
\hline \multicolumn{1}{|c|}{ Relation Between Construct } & $\begin{array}{c}\text { Original } \\
\text { Sample (O) }\end{array}$ & $\begin{array}{c}\text { T Statistic } \\
(|\mathrm{O} / \mathrm{STDEV}|)\end{array}$ & T Table & $\begin{array}{c}\mathrm{P} \\
\text { Values }\end{array}$ \\
\hline $\begin{array}{l}\text { Career Development -> Work } \\
\text { Satisfaction - > Turnover Intention }\end{array}$ & $-0,2523$ & 2,9831 & 1,97 & 0,0030 \\
\hline $\begin{array}{l}\text { Compensation -> Work Satisfaction } \\
\text {-> Turnover Intention }\end{array}$ & $-0,0876$ & 2,4387 & 1,97 & 0,0151 \\
\hline
\end{tabular}

The results from statistical calculations obtained were presented in tables 8 and 9 for structural model with these following hypothesis.

1) Hypothesis 1 - Career Development had significant influence towards work Satisfaction

Obtained a path coefficient of 0.657 and t count (10.011) > t Table (1.97) with p of 0.000 , thus H1 was accepted ( $\mathrm{p}<0.05)$ and H0 was rejected,therefore Career Development had significant positive influence towards work satisfaction.

2) Hypothesis 2 - Compensation had significant influence over work Satisfaction

An Obtained path coefficient of 0.228 with t count (3.375)> t Table (1.97) with p of 0.0008 , thus $\mathrm{H} 2$ was accepted $(\mathrm{p}<0.05)$ and $\mathrm{H} 0$ was rejected, therefore compensation had significant positive influence towards work satisfaction. 
3) Hypothesis 3 - Work Satisfaction had significant impact towards Turnover Intention Get Obtained path coefficient of -0.384 with $t$ count (3.300)> t Table (1.97) with $p$ of 0.001 , thus H3 was accepted $(\mathrm{p}<0.05)$ and H0 was rejected. Therefore Work Satisfaction had significant negative influence towards Turnover Intention.

4) Hypothesis 4 - Career development had significant impact on Turnover Intention Earned path coefficient of 0.052 and $t$ count $(0.416)<t$ Table (1.97) with $p$ of 0.678 , thus $\mathrm{H} 4$ was rejected $(\mathrm{p}<0.05)$ and $\mathrm{H} 0$ was accepted. so Career development has no significant positive influence towards Turnover Intention.

5) Hypothesis 5 - Compensation had significant influence towards Turnover Intention Obtained a path coefficient of -0.230 with t count (2.288)> t Table (1.97) with $\mathrm{p}$ of 0.0225 , thus H5 was accepted $(\mathrm{p}<0.05)$ and H0 was rejected, So compensation had significant negative influence towards Turnover Intention.

6) Hypothesis 6 - The Indirect Effect of Career Development on Turover Intention through work Satisfaction

Earned a path coefficient of -0.2523 with $t$ count (2.983)> t Table (1.97) with $p$ of 0.003 , thus H6 was accepted ( $<$ 0.05) and H0 was rejected, Therefore Career development had significant negative impact towards Turnover Intention through work satisfaction.

7) Hypothesis 7 - Indirect Influence from Compensation to Turnover Intention through work Satisfaction

Has earned a path coefficient of -0.0876 with $t$ count (2.4387)> $t$ Table (1.97) with $p$ of 0.0151, thus H7 was accepted ( $\mathrm{p}<0.05$ ) and H0 was rejected, Therefore Compensation had significant negative influence towards Turnover Intention through work satisfaction.

\section{CONCLUSION AND SUGGESTION}

\section{Conclusion}

Based on the research results and discussion in prior chapters these following conclusions could be drawn as in belows:

1) Career development variables had significant positive influence towards work satisfaction variables at AJB BUMIPUTERA 1912

2) Compensation variable had positive significant impact towards work satisfaction variable at AJB BUMIPUTERA 1912

3) Work satisfaction variable had negative significant impact on turnover intention at AJB BUMIPUTERA 1912

4) Career development variables had positive insignificant impact towards turnover intention at AJB BUMIPUTERA 1912

5) Compensation variable had significant negative influence to turnover intenTion at AJB BUMIPUTERA 1912.

6) Career development variables had significant negative indirect impact against Turnover Intention that mediated by work satisfaction at AJB BUMIPUTERA 1912.

7) Compensation variable had negative and indirect influence against turnover intention that mediated from work satisfaction at AJB BUMIPUTERA 1912. 


\section{Suggestions}

\section{Advice for Management}

1) Companies should be integrated HR planning well. So, to improve career development and work satisfaction, among the others such as:

a) Create a New Employee Orientation (NEO) program.

b) Create a clear career path by creating a career planning program for individual employees and organizations.

c) Create on the Job Training (OJT) program.

d) Perform evaluation and analysis of organizational structure and departmental analysis of each position to determine possible career movement opportunities for employees

2) Then the policies which could be carried out by companies related to compensation such as:

a) The company should provide employee rights in accordance with agreement set forth in Collective Labor Agreement (PKB)

b) Analyze the salary, compensation and benefits received by employee and should adjusted to resulting of performance so they would continue to be competitive and employees feel satisfied with salary that they get.

3) Policies that could be implemented by companies related to satisfaction which is:

a) Companies must provide more rewards and incentives to employee who exceed and have good performance.

b) Companies created Human Asset Value Mapping.

c) Create a People Development program.

d) Analyze those salaries, compensation and benefits for employee to keep them competitive and employees feel satisfied with the salary that they earned.

4) The impact of career development towards turnover intention was positive and insignificant. To improve career development and reduce employee intention to leave the company, this way could be done with:

a) Disseminate information about career development opportunities in the company.

b) Provide clear compensation and bonus system based on key performance indicators so employee feel satisfied because there has sense of justice

c) Give appreciation and rewards for employees who can complete the project well.

5) Those influence of compensation on turnover intention was negative and significant. Therefore had policies that could be carried out by company are:

a) By providing clear compensation and bonus system based on key performance indicators.

b) Give appreciation and rewards for employee who could complete the project well.

6) This indirect influence of career development on turnover intention through work satisfaction was negative and significant. policies that can be implemented by company such as:

a) Create employee relation programs. For Examples the programs that could be establish are watching movies together, sports competition events, company outings, and so on.

b) Create a clear career path and plan

c) Running a talent mapping system and people development and provide a clear reward system. 
7) There had negative and significant effect from compensation indirectly to Turnover Intention through work satisfaction. The employee policies which could be implemented include:

a) Make a clear compensation plan according to performance result.

b) Running a talent mapping system creates a clear reward system.

\section{Suggestions for Further Researchers}

These suggestions from the authors for further research were as its follows:

1) Researchers need to look for other variables which might have a relationship and influence on turnover intention and work satisfaction, such as leadership and organization environment.

2) A qualitative research approach should be tried as an alternative to the same research theme by adding employee as well as management.

\section{REFERENCES}

Dessler, G. (2013). Human Resource Management: Global Edition. Thirteen Edition. Pearson Higher Education.

Ghozali, I., \& H. Latan. (2015). Konsep, Teknik, Aplikasi Menggunakan Smart PLS 3.0 Untuk Penelitian Empiris . BP Undip. Semarang.

Jogiyanto, H. (2011). Metodologi Penelitian Bisnis: Salah Kaprah dan Pengalamanpengalaman. BPFE. Yogyakarta.

Kasmir. (2016). Manajemen Sumber Daya Manusia (Teori dan Praktik). Raja Grafindo Persada. Jakarta

Mathis, R. L., \& J. H. Jackson. (2013). Human Resources Management, Thomson Learning.

Mobley, W. H. (2011). Employee Substitution: Causes, Effects and Control (Translation) . PT Pustaka Binaman Pressindo. Jakarta.

Robbins, S. P., \& T. A. Judge. (2013). Organizational Behavior 15 years Edition . Pearson Education. New Jersey.

Sunyoto, D.. (2012). Teori, Kuisioner, dan Analisis Data Sumber Daya Manusia (Praktik Penelitian) . PT Buku Seru. Jakarta..

Nugroho, G. S., \& H. Aima. (2018). The Effects of Transformational Leadership and Compensation to Employee Performance on their Motivation and Its Implementation at $X$ Institution. International Journal of Scientific and Research Publications; Vol. 8. Issue $12,2250-3153$ 